\title{
Strike action by nurses in South Africa: A value clarification
}

\author{
Marie Muller, R.N.; D.Cur, Professor of Nursing, Rand Afrikaans University
}

\section{Abstract}

The Labour Relations Act (South Africa, 1991) made provision for protected strike action by employees, subject to certain conditions, procedures and negotiated agreements. This led to the removal of the strike clause in the Nursing Act (South Africa, 1992). The labour rights of all citizens are entrenched in the Constitution of the country (South Africa, 1996). Participation in strike action by the nurse/ midwife, regardless of the legal requirements and specifications, does, however, pose an ethical question. It is therefore necessary to conduct a value clarification on strike action by nurses in South Africa. The purpose of this research is to explore and describe the perceived values of participants from an accessible population on this phenomenon. A qualitative, exploratory and descriptive research design was deployed. The perceived values of nurses on strike action were collected by means of an openended questionnaire/sketch. Over a period of three years a purposive and convenient sampling method was used, involving all the enrolled post basic nursing/midwifery students/learners at a particular Nursing Education Institution. The justification of the sample was further enhanced by also collecting data on the participants' age and provincial distribution location. Although a $63 \%$ sample realisation (of the accessible population) was achieved, this represents only $1,5 \%$ of the registered nursing/midwifery population in the country. A descriptive analysis of the participants' age and provincial distribution was undertaken, as well as a content analysis of their perceived values on strike action. The mean age of the participants was 48 years, which could be attributed to the fact that most of them were enrolled for a post-basic Diploma in Community Nursing Science. Most of the responses $(52,7 \%)$ were against strike action and $32,5 \%$ supported strike action by nurses as a constitutional and legal right. A fairly substantial number of participants $(14,8 \%)$ expressed mixed views as to whether strike action by nurses is right or wrong. Some respondents $(15,7 \%)$ also reflected confusion regarding the enactment of strike action and the removal of the strike clause from the nursing legislation. Although this study does not claim external validity due to inappropriate representation of the nursing profession, the nurse of today opposes strike action. It is recommended that the study be replicated at national level and that the values be entrenched and published in position papers of and by the regulatory and organised nursing profession.

\section{Uittreksel}

Die Wet op Arbeidsverhoudinge (South Africa, 1991) maak voorsiening vir beskermde staking deur werknemers, onderhewig aan sekere voorwaardes, prosedures en onderhandelde ooreenkomste. Die arbeidsregte van alle burgers word in die Grondwet vervat (South Africa, 1996). Deelname aan stakings deur die verpleegkundige/ vroedvrou, lei, ongeag die wetlike bepalings, ook tot 'n etiese vraag. Dit is derhalwe belangrik om 'n waardeuitklaring oor stakings deur verpleegkundiges in SuidAfrika te onderneem. Die doel met hierdie navorsing is om waarde-persepsies oor hierdie verskynsel onder die toeganklike populasie te verken en te beskryf. Die waardepersepsies is by wyse van " $n$ oopeinde vraelys/skets versamel. Oor ' $n$ drie jaar periode is ' $n$ doelgerigte en gerieflikheidsteekproefneming uitgevoer, wat alle ingeskrewe, na-basiese studente/leerders betrek het. Verantwoording van die resultate is verder bevorder deur die insameling van die deelnemers se ouderdom en provinsiale verspreiding. Alhoewel 'n $63 \%$ steekproefrealisering (van die toeganklike populasie) bereik is, verteenwoordig hierdie getal slegs $1,5 \%$ van die verpleegkundige populasie in die land. 'n Beskrywende ontleding van die deelnemers se ouderdom en provinsiale verspreiding is vervolgens uitgevoer, asook 'n inhoudsontleding van die waarde-persepsies oor staking. Die gemiddelde ouderdom van die deelnemers was 48 jaar, wat moontlik toegeskryf kan word aan die groot aantal ingeskrewe studente vir die na-basiese Diploma in Gemeenskapsverpleegkunde. Meeste van die response $(52,7 \%)$ was gekant teen stakings en $32,5 \%$ het staking as ' $n$ grondwetlike en wettige reg beskou. 'n Redelike substantiewe aantal deelnemers $(14,8 \%)$ het gemengde persepsies oor stakings uitgelig. Sommig respondente $(15,7 \%)$ het ook verwarring oor die wetlikheid van stakings en die skrapping van die stakingsklousule in verpleegwetgewing gereflekteer. Alhoewel hierdie studie nie eksterne geldigheid op grond van ontoereikende verteenwoordigendheid kan proklameer nie, is die verpleegkundige vandag gekant teen stakings. Daar word aanbeveel dat die studie op nasionale vlak herhaal word en dat die waardes in standpuntmemoranda van en deur die regulerende en georganiseerde verpleegberoep uitgespel en gepubliseer word.

\section{Introduction}

A study on strike action by nurses/midwives in a particular nursing service (Mabange \& Muller, 2000) revealed both positive and negative experiences by the participants. The negative experiences related mainly to the emotional and moral 
issues. "A conflict of values in relation to strike action and patient care was expressed" (Mabange \& Muller, 2000:27). Strike action by nurses/midwives in South Africa was legally prohibited with the promulgation of the Nursing Act in 1978 (South Africa, Nursing Act no. 50 of 1978). In terms of this act, no nurse/midwife may participate in, or instigate a strike or go- slow strike (South Africa, 1978: section 40: 2(a), (b), (c)). For the purposes of this Nursing Act, strike and go-slow strike "... shall include any action by which the services rendered by persons registered or enrolled in terms of this Act are disrupted or likely to be disrupted" (South Africa, 1978: section 40, 2(b)). The strike clause of this Act was removed in 1992 (South Africa, Nursing Amendment Act, no. 21 of 1992) shortly after the Labour Relations Amendment Act (no. 9 of 1991) made provision for protected strike action by employees, subject to certain conditions, procedures and negotiated agreements between the employer and representative bodies/organisations.

The Constitution of the country (South Africa, 1996, section 23) makes provision for certain labour rights of every citizen, e.g. the right to fair labour practices, the right to strike, etc. Every employee in South Africa has the right to strike in terms of the new Labour Relations Act (South Africa, 1995:section 64), subject to certain conditions and procedures, such as being classified as an essential service, or in accordance with a negotiated agreement between the organisation and trade union. A protected strike therefore refers to the withholding of services subject to the legal procedures and conditions as stipulated in the Labour Relations Act (South Africa, 1995:section 64).

Participation in a strike action by a nurse/midwife, regardless of the legal requirements and specifications, does, however, pose an ethical question. This article focuses on a value clarification in respect of strike action by nurses/midwives in South Africa. A value refers to the emotional convictions, experiences, beliefs, dispositions, perceptions and preferences of a person with regard to people, things or happenings that are significant, important and valuable (Smith, 1992:12-13). There are many different values, e.g. universal, national, group or self values; religious, social relationship, moral, aesthetic, economic, cultural, political, legal, intellectual, physical, career values, etc. (Smith, 1992:16-24). This article will focus on the professional values of the nursing profession in relation to a specific phenomenon, namely strike action by the nurse/midwife.

The following research question is applicable: how do nurses/ midwives in South Africa perceive strike action? The purpose of this research is to conduct a value clarification on strike action by registered nurses in South Africa, by exploring and describing the perceived values of nurses regarding this matter.

\section{Terminology Strike action}

Strike action refers to the withholding of nursing/midwifery care in accordance with the legal requirements of the Labour Relations Act in relation to a protected strike (South Africa, 1995 as amended: sections 67/68).

\section{Perceptions}

A perception refers to the views, beliefs and opinions (reflected as values) of registered nurses/midwives regarding a specific behaviour/action within the context of the South African nursing profession.

\section{Value clarification}

A value clarification is the collective moral beliefs/disposition displayed by the nurses/midwives with regard to a specific phenomenon/action.

\section{Nurse}

A nurse is a practising, registered nurse/midwife who is registered with the South African Nursing Council in terms of the Nursing Act (South Africa, 1978, as amended).

\section{Research design}

A qualitative, exploratory and descriptive research design was deployed. An open-ended questionnaire/naive sketch was utilised as the method of data collection (Burns \& Grove, 1993:368-370). The following question was asked in writing: "How do you view/perceive strike action as registered nurses/midwives in South Africa?" The participants were also requested to reveal their age and the province in which they worked and resided. The population of the study included all the registered nurses/midwives in South Africa during 1997-1999. According to the South African Nursing Council (2000) there were 90923 registered nurses/midwives for the 1997 calendar year. The researcher determined the accessible population - portion of the target population to which the researcher had reasonable access - as all the students/ learners registered for a post-basic Nursing Science course/ qualification offered at a specific Nursing Education Institution in Gauteng, by means of residential or limited contact/ distance education at undergraduate level (see table one). A total of 2302 post-basic nursing/midwifery students were enrolled for the courses/qualifications at the Nursing Education Institution during 1997 to 1999 (the students from neighbouring countries were excluded from this figure). A substantial number were enrolled for the post basic Diploma in Community Nursing Science $(\mathrm{N}=830)$ which could have influenced the average age of the participants. The residential, post basic degree, B.Cur. (Ed et Adm), was also well represented $(\mathrm{N}=609)$ which in turn could have influenced the Gauteng geographical representation of the accessible population and sample.

A purposive and convenient sampling method was utilised (Burns \& Grove, 1993:245) in the selection of participants complying with the following inclusion criteria:

- $\quad$ Registered with the South African Nursing Council as a general nurse and/or midwife.

- $\quad$ Enrolled as a student for any post basic Nursing Sci -ence course/qualification offered by a university, by means of residential and/or distance/consolidated tui -tion, during 1997 to 1999 , at undergraduate level.

- Class/group session attendance by the participants on the selected data collection days. 


\begin{tabular}{|c|c|}
\hline Qualification/course & $\mathbf{N}$ \\
\hline B.Cur. (Ed et Adm.) & 609 \\
\hline Diploma in Nursing administration & 90 \\
\hline Nursing Science & 96 \\
\hline Diploma in Advanced Nursing Dynamics: Unit \\
Management & 230 \\
\hline Diploma in Medical and Surgical Nursing Science & 210 \\
\hline Diploma in Primary Health Care: Diagnosis, & 235 \\
\hline Creatment \& Care & 210 \\
\hline
\end{tabular}

The questionnaires/sketches were distributed to all post basic nurses/midwives enrolled for the post basic Nursing Science courses/qualifications offered by the university when they attended a particular class/group session in 1997, 1998 and 1999. The purpose of the research was explained and confirmation of adherence to the ethical standards of research in relation to their rights, were given. Written, informed consent was obtained from those who indicated a willingness to participate.

A descriptive analysis of the participants' ages and provincial distribution was undertaken. A content analysis on their perceptions was applied as described by Tesch (1990). The principles of trustworthiness, as described by Lincoln and Guba (1985:290) and Beeby (in Thomson, 1997:181-200) which relate to credibility, confirmability, dependability and transferability were applied:

- $\quad$ Rigour in data analysis by applying the principles of content analysis as described by Tesch (1990).

- Investigator triangulation or member checking by using three independent researchers to assist in the data analysis and discussion of the main themes resulting in a consensus debate.

- Data triangulation during a feedback and debate session with selected participants three months after data collection.

- Limited literature control due to the scarcity of sources/ literature on the topic of strike action by nurses/midwives in South Africa.

The ethical standards of nursing research, as described by DENOSA (1998), were adhered to in relation to informed consent, anonymity and quality of research.

\section{Results}

The results are presented in relation to the sample realisation and a descriptive/exploratory analysis of the nurses' perceptions on strike action within the nursing profession of South Africa.

\section{Sample realisation}

A total of 1458 participants gave consent and completed the

\section{Table 2: Realisation of sample}

\begin{tabular}{|l|c|c|}
\hline \multicolumn{1}{|c|}{ Province } & $N$ & $\%$ \\
\hline Eastern Cape & 390 & 26,8 \\
\hline Free State & 26 & 1,8 \\
\hline Gauteng & 607 & 41,7 \\
\hline Kwazulu Natal & 46 & 3,2 \\
\hline Mpumalanga & 209 & 14,4 \\
\hline Northern Cape & 5 & 0,4 \\
\hline Northern Province & 164 & 11,2 \\
\hline North West & 7 & 0,5 \\
\hline Tota I & 1458 & 100 \\
\hline
\end{tabular}


questionnaire/sketch during 12 different lecturing/group contact sessions on campus in 1997, 1998 and 1999. This reflects a $63 \%$ sample realisation. Gauteng Province reflected the highest representation $(41,7 \%)$, followed by Eastern Cape $(26,8 \%)$ and Mpumalanga $(14,4 \%)$ as reflected in table two. This is by no means representative of the registered nursing/ midwifery population in South Africa as it constitutes approximately $1,5 \%$ of the population. The average age of the participants is 48 years, which gives a biased reflection of the "older" professional's perceptions on strike action (see table three). This could be due to the fact that most of the selected accessible population $(\mathrm{N}=833 ; 36 \%)$ were enrolled for the post basic Diploma in Community Nursing Science (see table one), which means that they completed their basic nurse training prior to 1984 when the comprehensive four year course was introduced. doesn't suit the profession." "I feel it is very unfair for a professional person to leave a sick patient alone and go on strike." "Strikes should be avoided by all costs." "To me strikes are wrong." "Striking doesn't solve the problem and should never be allowed." "I think I don't like strikes. I cannot imagine myself being seen on television jumping with card boards like a little girl." "Striking by a registered nurse is unacceptable and wrong. It gives a wrong picture of the profession." "Striking is a medical-legal hazard and should be banned." "Striking endangers the patients' lives and should never be allowed." "I don't believe in strike action - I chose nursing and should uphold my promise to the community." "A person that goes on strike must choose another job." "Nurses must never strike because we deal with the lives of human beings. We have to promote life, alleviate suffering and prevent complications. So let's solve the problems and

\section{Table 3 : Distribution of age}

\begin{tabular}{|c|c|c|}
\hline Range of age & $\mathbf{N}$ & $\mathbf{\%}$ \\
\hline $20-29$ & 278 & 19,1 \\
\hline $30-39$ & 295 & 20,2 \\
\hline $40-49$ & 535 & 36,7 \\
\hline $50-59>$ & 350 & 24 \\
\hline Total & $\mathbf{1 4 5 8}$ & $\mathbf{1 0 0}$ \\
\hline
\end{tabular}

\section{Descriptive and exploratory analysis}

Three categories were identified: strike action by nurses is unacceptable/wrong, strike action by nurses is acceptable and a third group that was indecisive/unsure (see table four). It was also clear that many participants were confused with respect to the constitutional and legal rights of nurses to participate in a protected strike today.

\section{a) Strike action by nurses is wrong}

Many of the participants $(52,7 \% ; \mathrm{N}=768)$ were opposed to strike action; they perceived strike action by nurses as unacceptable/wrong. Randomly selected direct quotations are presented: "Strikes retard health services, misuse government properties and promote crime." "Strike action is wrong because of negligence of patients and resultant death." "Registered nurses should never be allowed to strike - it is against our code of ethics." "Striking is wrong, destructive and degrading." "Striking is against my beliefs and very wrong - it continue caring for our patients." "There are enough structures and procedures that can be followed - so strike action by the nurse is wrong." "I do not like strike action by nurses. It lowers our dignity to see nurses dancing, shouting and doing funny things in front of the TV screen." "I feel it is bad for nurses to indulge into strike actions as they deal with peoples' lives. I feel there are enough strategies to deal with the problems and to address grievances." "Striking is very bad and wrong as it affects the patients' health and the community as a whole." "Strike action by nurses is not advisable because patients are left suffering." "Strikes are very bad actions." "Despite grievances by nurses, they should avoid strike action at all time for the sake of the community." "No strike action is ever appropriate to address grievances of any type." "Nurses should never go on strike but utilise their channels of communication." "I do not support strike action by nurses." "Strike action is not the answer to the problems." "Nurses should not go on strike but rather negotiate their prob- 
lems." "Nurses should consider the consequences of strike action - I don't support strike action." "Strike action is unethical because it is the patients that suffer, not the management." "Nurses must stop striking because they are life savers of the community." "Strike action by nurses is disgusting due to the fact that patients are always the sufferers." "I do not favour strike action - rather sit and negotiate." "Nurses on strike is not a nice thing to see or to experience and should not be allowed." "Nurses striking should be dismissed from the role." "It is not acceptable - patients suffer at the end of the day with lowering of our professional standards and respect from the community." "I dislike strike because during strikes the one who is suffering is the patient." "Striking is very unprofessional." "Very unprofessional and degrading." "Striking is a wrongful action." "Strike action is bad - it is really a shame." "Nurses are professional people who should always be a role model and should never leave their patients alone." "Strike action is unprofessional, unethical and insensitive." "I am definitely against strike action - it is still a big NO". "I hate strike action because we achieve less from it and do more harm to our patients, the community and our profession." "Striking is not a good thing - it degrades the
It is therefore clear that most of the participants reflected very strong views and feelings against strike action due to the negative effect it has on the patient and community, the professionalism of the nursing practitioner and on the professional status of the nursing profession as a whole.

\section{b) Strike action by nurses is acceptable}

A total of $474(32,5 \%)$ participants supported strike action by nurses. All these participants who supported strike action by nurses emphasised their right to strike. Selected quotations are given: "Nurses have the right to strike if they are dissatisfied with their working conditions." Strike action by nurses is acceptable to me." "Nurses should strike in order that their needs are met by the employers." "Strike action is the only effective way to draw the attention of the government." "Nurses have the right to strike provided it is done according to the legal requirements and with dignity." "Nurses should go on strike if negotiations have failed." "Nurses should be permitted to strike and this should not be criticized because we are also employees." "Being a nurse does not

\section{Table 4: Distribution of main themes}

\begin{tabular}{|l|c|c|}
\hline \multicolumn{1}{|c|}{ Theme } & $\mathbf{N}$ & $\mathbf{\%}$ \\
\hline Strike action is acceptable & 474 & 32,5 \\
\hline Strike action is unacceptable/wrong & 768 & 52,7 \\
\hline Indecisive/unsure & 216 & 14,8 \\
\hline Total & 1458 & $\mathbf{1 0 0}$ \\
\hline
\end{tabular}

profession." "I am against strike action because we deal with life and not objects - a life cannot be replaced." "It is not decent for nurses to strike." "It is a shame really, and it shows a lack of responsibility." "Striking is wrong. It cripples the health system - it has bad effects on the community, patients and our profession." "Our professional dignity is lost by striking." "It makes nursing to lose it's value." "Striking is a disaster. We are victimised and chased away from our patients." "It damages the image of nursing - it is a disgraceful conduct." "It is wrong because it leads to human negligence - it is a danger to the patients." "It contradicts our pledge of service." "Under no circumstances should nurses strike - it is unethical, unprofessional and disgraceful. It is also a waste of money." make us different from other citizens and therefore we have the right to strike." "General workers are recognised to have the right to strike - so why not nurses?" "Strike is OK." "It is high time that nurses can also go on strike." "It is excellent because the government seem to ignore the nurses' grievances because of their pledge." "Strike action is the best way of showing dissatisfaction." "It is necessary for nurses to strike and to show our power in order to attain our goals." "Nurses must strike because nobody cares about us. Even the President talks about other categories such as police, teachers but not about nurses." "Nurses can strike because they are individuals and they have the right to be respected." "Striking allows us to push the situation and to make our demands known." "Everybody has the right to strike - so do nurses." 
"Nurses can go on strike as long as they bear in mind that the consequences should not involve the loss of human life." "Organised strike action by nurses is allowed and acceptable." "Good when needed." "The new South Africa does not have an ear unless you embark on strike action." "We must liberate our minds and accept that nurses are also South African citizens and have the right to strike without being victimised." "Nurses should be able to go on strike because the government does not consider nursing as a profession - we earn less money than others with an easier job." "Nurses must go on strike - it is the right thing to do in the new South Africa." "Our working conditions are disgusting. Striking is the only option left." "I encourage strike action by nurses if negotiations have failed." "We are not recognised as professionals. Therefore we must go on strike." "Strike action is right and it is high time that everyone accepts it." "It is my democratic right to go on strike if the employer ignores my needs." "Strike action by nurses is the only way to express our problems and needs." "In order to fight for my rights I should be able to go on strike - there is no other way to convince the government of the day." "We should go on strike because we are lacking behind other workers." "Striking is OK provided we leave a skeleton staff behind." "It is the only way of attracting the attention of the government." "Strike action is needed as long as it is well organised." "Strike action in South Africa simply shows that the needs of nurses have long been neglected; now they are reacting to the pressure they have been exposed to." "If you don't get what you want you are absolutely going to resort to strike action." "Strike action is the only way to speed up the action required. Negotiations take too long and the results are never fruitful." "I believe in striking by nurses as a means of expressing our grievances when the employer refuses to listen." "Nurses have to strike - they must strike due to poor salaries and unacceptable working conditions." "Strikes are there to force attention." "Nurses must strike because we are not represented where it matters." "Ignore our grievances and we will strike." "We are also workers and must be able to strike like all other workers in South Africa." "Striking is the only way of fighting for our rights. We have been ignored for too long." "We indulge in strike action because government only attend to grievances if you strike." "Strike is legal and right and we need to liberate our minds and change the values." "Striking is good - it is the way of bringing about change today." "Striking is good if there is no job satisfaction and adequate remuneration." "There is nothing wrong with strike action today." "I have no objection to strike action by nurses." "It is legally acceptable - so change the old fashioned views." "It is the only tool we have in hand if we are not satisfied with our salaries and working conditions." "Gone are the days where a nurse was oppressed just for the sake of our pledge. Striking is the only way out." "Strike is the way of talking today." "It is a constitutional right and the democratic way to do things today." "We are underplayed all the time. Striking is the only way." "Nurses are not super humans - enough exploitation! Striking is the only way out." "We should also be treated with respect and justice. Government doesn't do that so now we must strike." "Overworked and underpaid. Striking is the only option." "If we continue to allow oppression we must pay for it. Rather go on strike and show strong leadership in this way." "We are tired of suppressed emotion forced by the professional-ethical obligation - striking is long overdue." "Strike is the only language understood by the authorities today. Even the President of the country has the nerve to tell us to go to work or to resign."

With these quotations the participants reflect aggression towards their working conditions and salaries. It is also clear that the principles of democratisation within the workplace have not been adequately implemented and that there is a poor trust relationship between the nurses as employees and their employers and higher decision making bodies/authorities.

\section{c) Indecisive}

A substantial number of participants $(14,8 \%$; $N=216)$ expressed mixed views as to whether strike action by nurses is right or wrong. Indecisiveness in this research refers to a mixed view by the participant, which is either a neutral comment, or a comment reflecting support for both dimensions: strike action is wrong/unacceptable, but reservations are expressed that could justify strike action by nurses.

The following quotations are presented in support of this category: "I think is it unprofessional for nurses to strike - but on the other hand it is our right if management don't react on our grievances. Government must know that we are working too much and working with peoples' lives is not a child's play." "Although strike action is unprofessional, it is OK. It is painful to see people dying unnecessarily." "Strike action by nurses is unprofessional and causes suffering to patients. But should be allowed nevertheless." "Patients will continue to die, even with 5 doctors around them. The community must be with us because what problems they encounter where they work - it is also our problem - let the nurses do their thing." "We have to remember our oath, but the patient must also understand our problems." "Nurses should be allowed to say their views on matters pertaining to their sphere of work but not to leave the sick patients unattended. But they are also human beings which allows them to strike." "I do not agree with it due to my nurses' pledge which I do respect. BUT, due to grievances, poor salaries, no holiday allowance, it must be accepted." "Patients should not suffer. Government should meet our needs, even if it means that we have to strike." "Nurses are not supposed to leave patients unattended. But government is exploiting this and they should know that nurses also have rights." "Strikes deprive patients of care, but sometimes it is necessary for nurses to strike. It is not right to do it, but nurses are compelled to go into strike action." "I sympathise with the patients that face being left unattended at the time of the strike. But nurses are also people with families and emotions and they need every care like anybody else." "I don't think nurses like to strike; I don't think it is right to go on strike. But circumstances force them to strike because the authorities don't listen to our problems." "The patient comes first. But what else can we do if our grievances are not solved?" "Strike is not right. We want our needs to be met by the government and if this means we have to go on strike to meet our peoples demands - we need to strike." "Strike is right as long as life and care of the patient is not compromised." "Strike is only right if patients are not neglected and don't die." "Strike action by the nurse is not so good but not so bad too." "Nurses are affiliated to so many unions of which some are even confused by their objectives. We are forced to go the way of the union." "Strike is wrong but compulsory if good reasons are given, as long as the com- 
munity doesn't suffer." "My view with regard to strike action is that they should not go on strike, but seeing that the government which leads us cannot listen to negotiations, we can go on strike but at least leave some people to cater for emergencies." "It is a method of expressing their needs so that their demands can be met. But it is also heartbreaking if the people suffer due to strike actions." "Nurses are there to promote health and to prevent illness and not to put the patient's life in danger. But striking is allowed if necessary." "Strike is not good for the patient and for the profession. Sometimes it is good for nurses especially if their requests are not taken into consideration and not considered as human beings." "I don't think they must strike. But at the same time nurses' needs must be met accordingly and striking is then OK." "I have very mixed feelings about strike action by nurses. Human lives are at stake. But nurses are also human beings and have the right to strike." "It is not good to strike because patients lose their lives; loss of security and safety. We have to preserve life but cannot do it if our demands are not met. Therefore nurses should be allowed to strike." "It is not right to strike. But it looks like nurses are non-existing when it comes to salaries. They are not regarded by government as important people. So strike is the only option." "Every individual has his/her own personal views regarding health. Again every person is unique and has the right to quality health care. For us to do a good job we have to be awarded." "I don't really know. Participating in strike action is to let our dignity down because the community put their trust in us. But outside we are not regarded as respected people. We must try our best." "This is a difficult question. Nurses are working under difficult conditions and the authorities do not listen to our concerns. It is not wise to let patients suffer during strike action and violence." "There are many problems facing nurses. So I don't know." "It should not be allowed. Demoralising for myself. But what about our demands?" "Liberty of conscience." "We need protection by our unions. They should decide what is best for us." "Striking is lowering the professional standards and status and also losing confidence and trust by the community. But how else can our grievances be met?" "Striking is morally and ethically wrong. We are duty bound to perform our work. But we are dissatisfied with our salaries and conditions of service. So?" "Money wise to meet our basic needs - then the will to strike won't be there." "I don't like strikes. But sometimes we aie forced to do things we don't like." "I think strikes are wrong. I think negotiations are best - but our needs must be met or we will fight for our rights." "I personally do not like strikes. It is my prayer not to jump since I have not yet jumped. But I will jump if I am forced to do so." "Because of the patients we musn't strike. But because of the nurse we can strike."

\section{d) Confusion}

During the analysis of the questionnaires/sketches, it was also clear that many participants $(15,7 \% ; \mathrm{N}=230)$ were not informed regarding the content of the Labour Relations Act (South Africa, 1995) and the amendment of the Nursing Act (South Africa, 1992) as they stated that no nurse can go on strike; it is illegal for any nurse to participate in strike action. These participants did, however, also give their views on strike action as to whether it was right or wrong. Their perceptions could have been influenced by their lack of insight into the legal changes in South Africa.

\section{A value clarification on strike action by nurses: literature analysis}

A brief literature analysis is presented in respect of the fundamental professional values stated by the South African Nursing Council, the South African legislative principles on strike action, the position paper by the International Council of Nurses, as well as the draft position paper of the Democratic Nursing Organisation of South Africa.

Since the removal of the strike clause from the Nursing Act (South Africa, 1992) and the enactment of strike action in the Labour Relations Act (South Africa 1991;1995), great uncertainty has arisen amongst nurses and in the community in general regarding the current position of nurses with respect to strikes. The South African Nursing Council (1992:iv) does, however, make the professional-ethical principles very clear: "The citizens of South Africa have the right to a nursing service which creates and maintains a disciplined, safe nursing environment that is accessible to patients, conducive to health, free of neglect and malpractice and free of harassment and intimidation." Professional values fundamental to nursing practice are delineated by the South African Nursing Council (1992:3) in their policy on ethical considerations in nursing: Respect for the person as a total being, respect for human life as well as for the vulnerability of life; commitment to accountable safe practice; compassionate involvement and personal integrity. The rights of the patient with special needs are also outlined within this policy statement. focusing on the high risk newborn infant, as well as the unusually vulnerable patient (SANC, 1992:4-6). These are the types of nursing care that could be viewed and negotiated as essential services. The rights of the nurse are also outlined by the South African Nursing Council (1992:15-16) in this policy statement: to enable the nurse to provide safe and adequate nursing in the interest of quality health service delivery. This policy statement has, however, not been revised within the framework of the transformed regulatory body. The professional and legal responsibilities of the nurse/midwife are outlined as the scope of practice in Government Notice R2598 (1984, as amended). Failing to carry out these professional responsibilities could lead to disciplinary action by the South African Nursing Council. The nurse/midwife has a professional and legal obligation to maintain the health status of a patient under his care or charge in relation to correct patient identification, determining the health status of the patient and the physiological responses of the body to disease conditions, trauma and stress; the correct administration of treatment, medication and care; the prevention of accidents, injury or other trauma; the prevention of infection; the checking of all forms of diagnostic and therapeutic interventions for the individual; specific care and treatment of the patient and the monitoring of all the vital signs of the patient concerned (Government Notice R387, 1985 as amended: section 4). This could imply that strike action by a nurse/midwife could be seen as unprofessional conduct.

The International Council of Nurses (1992 in 2000: http:// www.icn.ch/policy.htm) highlights the background and recent developments in respect of labour rights as well as the professional-ethical and legal obligations of nursing practitioners: "The fundamental responsibility of the nurse is four- 
fold: to promote health, to prevent illness, to restore health and to alleviate suffering". In certain cases, nurses may find themselves in situations where strike action is necessary to ensure the future delivery of quality care by qualified personnel (ICN, 1992:2). The International Council of Nurses (ICN, 1992:2) expects nurses to have equitable remuneration and acceptable working conditions, including a safe environment. As employees, nurses have the right to organise, to bargain collectively and to take strike action. ICN defines a strike as employees cessation of work or a refusal to work or to continue to work for the purpose of compelling an employer to agree to conditions of work that could not be achieved through negotiation. Strike action is considered the last resort, only after all other possible means to conclude an agreement have been explored and utilised. Effective industrial action is compatible with being a health professional as long as essential services are provided. Abandonment of ill patients is inconsistent with the purpose and philosophy of professional nurses and their professional organisations as reflected in ICN's Code of Ethics for Nurses. During a strike, the principles to be upheld include:

- The minimum level of disruption to the general public;

- The delivery of essential nursing services to a reduced patient population;

- Crisis intervention by nurses for the preservation of life;

- Ongoing nursing care to assure the survival of those unable to care for themselves;

- $\quad$ Nursing care required for therapeutic services without which life would be jeopardised;

- $\quad$ Nursing involvement necessary for urgent diagnostic procedures required to obtain information on potentially life threatening conditions;

- Compliance with national/regional legislation as to the procedure for implementation of strike action.

The nurses' right to take industrial action in the case of a breakdown of negotiations may only be curtailed if independent and impartial machinery such as mediation, conciliation and arbitration are established. The ICN also emphasises the role of national nurses' associations which should be responsible social partners and must develop training programmes that adequately prepare their representatives, nursing leaders and nurse employees in practice of the various methods of negotiation as a means for resolving their employment concerns - i.e. conciliation, arbitration, collective bargaining as appropriate in 'each country/province. They further emphasise the importance of developing pro-active policies and contingency processes, as well as structures to guide their members' professional attitude and behaviour during such situations (ICN, 1992).

It is therefore clear that the International Council of Nurses supports an organised and protected strike action by nurses if their labour rights are not adhered to, but in accordance with the professional and legal framework of a country and the subsequent policies and procedures.

The Democratic Nursing Organisation of South Africa (DENOSA) has not yet developed a new position paper on indus- trial action by nurses, but has adopted previous position papers that were compiled by the respective nursing organisations as draft policy statements until these have been amended. The existing draft position paper on strike action by nurses was compiled in 1992 and adopted by DENOSA in 1997 and reads as follows: Strike action by nurses is a violation of the patient's right to safe and continuous nursing; nurses should never be placed in a situation where they feel there is no other option open to them. Nurses therefore have a right to fair and equitable practices; reasonable conditions of employment; a fair dispute resolution procedure which must be negotiated and agreed to by the employer and the representative organisation for nurses and which should exclude strike action but include compulsory arbitration. Nursing services should be declared essential services in both the public and private sector, thus entrenching the right to compulsory arbitration. Strike action as a means of resolution between employers and nurses is not condoned; strike action by nurses which endangers the patient's right to safe and continuous nursing care constitutes unprofessional conduct. Intimidation of nurses who refuse to strike is condemned (DENOSA, 1997).

The right to strike is entrenched in the Labour Relations Act (South Africa, 1995 as amended: section 64). This Act (South Africa, 1995, as amended: section 65) places limitations on strike action: a person may not participate in a strike action if that person is bound by a collective agreement that prohibits strike action, is involved in a dispute that should be referred to arbitration or if that person is engaged in an essential or maintenance service. The Act also stipulates the conditions/ requirements of secondary strikes (South Africa, 1995 as amended, sections 66/67). A protected strike refers to strike action that is compliant with the conditions of chapter four of this Act (South Africa, 1995 as amended: section 67). As nursing/midwifery care has not been declared as an essential service, a negotiated agreement can be reached between the employer and representative organisation in relation to strike action and dimensions of nursing/midwifery care to be classified as essential services. It is, however, important to develop a Code of Ethics in accordance with the international and national professional values of the nursing/midwifery profession in South Africa.

\section{Conclusions and recommendations}

The following conclusions are made:

- The perceived values on strike action as reflected by the participants, are not representative of the nursing profession in South Africa.

- The participants in this research are from the older age group (mean age 48 years).

- $\quad$ Most of the participants $(41,7 \%)$ represented Gauteng province, followed by Eastern Cape $(26,8 \%)$ and Mpumalanga $(14,4 \%)$.

- Many participants $(52,7 \% ; \mathrm{N}=768)$ oppose strike action by nurses.

- The participants opposing strike action justify this due to the negative effect it has on the patient/community, the professionalism of the nursing practitioner and the professional status of the nursing profession in South Africa. 
- A fairly substantial number of participants $(32,5 \%)$ support strike action by nurses.

- The participants supporting strike action by nurses display a high degree of aggression and dissatisfaction with respect to their salaries, working conditions and employee/employer relationships.

Some participants $(15,7 \%)$ display confusion in relation to the legality of a protected strike action by nurses in South Africa.

The following recommendations are made:

- A national replication of this study - a combined effort by the regulatory and organised nursing profession - to conduct a national value clarification of strike action by nurses.

- The South African Nursing Council should compile/ develop a position paper on professional, fundamental and labour values.

- The Democratic Nursing Organisation of South Africa should compile/develop a position paper on industrial action by nursing practitioners in South Africa, as well as the policies, procedures and conditions applicable during industrial action in accord -ance with the international and national professionalethical and legal framework of the nursing profession.

- Continuous professional education of nurses on their professional-ethical and legal responsibilities and rights.

\section{Limitations}

External validity - the extent to which the study findings can be generalised beyond the sample used in the study - cannot be claimed. The sample is not representative of the registered nursing/midwifery population/profession in relation to numbers, geographical distribution and age.

\section{Acknowledgements}

The participants are sincerely thanked for their willingness to participate in this research by giving their perceived values on the topic under study.

\section{References}

BURNS, N \& GROVE, SK 1993: The Practice of Nursing Research. Conderct. Critique \& Utilization. Philadelphia: WB Saunders.

DENOSA 1997: Draft Position Paper on Industrial action by members. Pretoria: DENOSA.

DENOSA 1998: Ethical Standards for Nursing Research. Pretoria: DENOSA.

GOVERNMENT NOTICE R2598 1984 (as amended): Regulations relating to the scope of practice of persons who are registered or enrolled under the Nursing Act, 1978. Pretoria: State Press.
GOVERNMENT NOTICE R387 1985 (as amended):

Rules setting out the acts or omissions in respect of which the Council may take disciplinary steps. Pretoria: State Press.

INTERNATIONAL COUNCIL OF NURSES 2000: ICN Position Statements - Strike Policy. Geneva: ICN (www.icn.ch/policy.htm).

LINCOLN, YS \& GUBA, E 1985: Naturalistic inquiry. London: Sage.

MABANGE, E \& MULLER, ME 2000: Strike action by nurses/midwives in a nursing service. Health SA Gesondheid. 5 (1): 22-37.

SMITH, DPJ 1992: Die Ontologie van Waardes. Johannesburg: Randse Afrikaanse Universiteit (ongepubliseerd).

SOUTH AFRICA 1978: Nursing Act (Act 50 of 1978). Pretoria: Government Printers.

SOUTH AFRICA 1992: Nursing Amendment Act (Act 21 of 1992). Pretoria: Government Printers.

SOUTH ARICA 1995: Labour Relations Act (Act 66 of 1995). Pretoria: Government Printers

SOUTH AFRICA 1996: Constitution of the Republic of South Africa (Act 108 of 1996).

SOUTH AFRICAN NURSING COUNCIL 1992: Standards for Nursing Practice. South African Nursing Council Policy Statements. Pretoria: SANC (unpublished).

SOUTH AFRICAN NURSING COUNCIL 2000: Statistical Returns for the Calendar Year 1997. Pretoria: SANC.

TESCH, R 1990: Qualitative Research: analysis, types of software tools. New York: Palmer Press.

THOMSON, S (Editor) 1997: Nurse Teachers as Researchers: a Reflective Approach. London: Arnold. 